Featured Essay

\title{
Césaire's Revolution of Pedagogy
}

\section{Mark W. Westmoreland}

\begin{abstract}
Just as Césaire called for revolutionary practices that would put an end to colonization, its corrupt institutions, and its dehumanizing policies, his words still speak truth to a world marred by neocolonialism and rampant inequalities. His call for revolution continues to challenge us to create "a humanism made to the measure of the world." In this essay, I turn to his Discourse on Colonialism and suggest that his critique can still be useful for the twenty-first century. First, I provide an account of Césaire's diagnosis of the brutality of colonialism. Second, I consider the role of public intellectual. I argue that the self-determination of colonized peoples, dialogue, and radical change of institutions are necessary ingredients for forming a nonmanichaean humanity.
\end{abstract}

Keywords: Césaire, pedagogy, revolution, intellectuals

17 et the peoples speak. Let the black peoples come onto the great stage of history." 1 These words were spoken by Aimé Césaire at 1956 Congress of Black Writers and Artists in Paris. His words raise questions about who speaks, with what content does one speak, and how, or in what manner, one speaks. What will the colonized say? In "Black Orpheus," Jean-Paul Sartre writes, "When you removed the gag that was keeping these black mouths shut, what were you hoping for? That they would sing your praises? Did you think that when they raised themselves up again, you would read adoration in the eyes of these heads that our fathers had forced to bend down to the very ground? Here are black men standing, looking at us, and I hope that you-like me-will feel the shock of being seen." 2 The colonial white gaze attempts to trap black persons under the white gaze, which is both the lens and action through which whites viewexplicitly or implicitly-black persons. It filters that view so that the default way of seeing black persons is that they are ignorant or threatening. But Sartre

${ }^{1}$ Aimé Césaire, “Culture and Colonization," Social Text, 28:2 (2010), 142.

2 Jean-Paul Sartre, "Black Orpheus," in Race, ed. by Robert Bernasconi (Malden, MA: Blackwell, 2001), 115.

(C) 2018 Mark W. Westmoreland

https://www.kritike.org/journal/issue 23/westmoreland december2018.pdf

ISSN 1908-7330

(cc) BY-NC-ND 
has borne witness to the countergaze in which the insidious nature of whiteness is called out. A new world begins.

The fundamental question of the so-called postcolonial moment is about revolutionary practice, namely, what does it mean to begin? At the same time, an answer requires a new kind of pedagogy-one of destroying the world in order to lead into another. In his poem "The Thoroughbreds," Césaire writes:

\author{
As everything was dying, \\ I did, I did grow - as big as the world- \\ and my conscience wider than the sea! \\ Last sun. \\ I explode. I am the fire, I am the sea. \\ The world is dissolving but I am the world
}

The end, the end did we say. ${ }^{3}$

On this passage, John Drabinski comments that "the end of the world is what makes consciousness possible and makes consciousness wider than the seaperhaps exceeding, in its beginning again, the catastrophe represented by the sea, where the history and memory of Africa were drowned." 4 If the pedagogue's aim is to critique the present in order to create new horizons of the imaginary, then there exists a need to grasp the ever-present tension between past and future. Paulo Freire suggests that "the point of departure must always be with men and women in the 'here' and 'now,' which constitutes the situation within which they are submerged, from which they emerge, and in which they intervene." 5 In addition to the temporal dimension of the critique of the present, there is a spatial dimension which inclines one to begin with the situation of the marginalized, the oppressed, the wretched of the earth. There is no neutral standpoint since there is no individual or group that is not within a social world. Alice Walker writes, "I believe that the truth about any subject only comes when all sides of the story are put together, and all their different meanings make one new one." ${ }^{\prime}$ Each epistemic group contributes partial (not universal) knowledge, situated knowledge. To speak briefly, Patricia Hill Collins in Black Feminist Thought

\footnotetext{
3 Aimé Césaire, "The Thoroughbreds," in The Collected Poetry, trans. by Clayton Eshleman and Annette Smith (Berkeley, CA: University of California Press, 1983), 101.

4 John E. Drabinski, "Césaire's Apocalyptic Word," South Atlantic Quarterly, 115:3 (2016), 574

${ }^{5}$ Paulo Freire, Pedagogy of the Oppressed (New York: Continuum, 2007), 85.

${ }^{6}$ Alice Walker, In Search of Our Mother's Gardens (San Diego, CA: Harcourt Brace Jovanovich, 1983), 49.
}

(c) 2018 Mark W. Westmoreland https://www.kritike.org/journal/issue 23/westmoreland december2018.pdf ISSN 1908-7330 


\section{CÉSAIRE'S REVOLUTION OF PEDAGOGY}

offers one necessary but insufficient remedy to injustice: dialogue. Dialogue is not two monologues happening concurrently. Rather, it implies empathy and call-and-response. Dialogue implies a genuine attempt to understanding how, to borrow from Nikki Giovanni, "the universal comes from the particular." 7 Collins suggests that black feminist epistemology refuses the universalizing of positivism, which separates the knower from the thing known, eschews emotion, disavows values with regard to facts, and approaches knowledge through adversity. Collins also claims that advocating for situated knowledge is not the same as advocated for relativism. The latter treats all knowledge claims as equally valid. For Collins, however, one's position in the social matrix grants a particular perspective, and some perspectives give better insight into the phenomenon under investigation. For Césaire, the phenomenon is the racialized domination of colonialism. This new historical-critical consciousness is brought about by a new education-one that takes seriously the Archimedean point of contextualized everyday lived experience.

In this paper, I turn to Césaire's Discourse on Colonialism and suggest that his critique can still be useful for addressing neocolonial and racial injustice in the twenty-first century. First, I provide an account of Césaire's diagnosis of the brutality of colonialism and racialized capitalism. Second, I consider the role of the public intellectual. Many public intellectuals espouse a humanism that remains Eurocentric. However, for Césaire, there are positive future possibilities that the public intellectual can aid in making manifest, namely, the self-determination of colonized peoples, dialogue, and radical change of institutions for forming a nonmanichaean humanity.

\section{Creating a Politico-Aesthetic Imaginary}

Colonialism, as Césaire conceives it, is a totalizing scheme of inside/outside, of the systems of the colonizer and the interior life of the colonized. Colonization, for Césaire, is decivilization. It is he writes, "neither evangelization, nor a philanthropic enterprise, nor a desire to push back the frontiers of ignorance, disease, and tyranny, nor a project undertaken for the greater glory of God, nor an attempt to extend the rule of law." 8 What Charles Mills calls "the racial polity" refers to the system of domination in which races are categorized and ascribed value. The racial contract, which is what sustains the racial polity, is, for Mills, an epistemological contract. Where recognition is understood as an agreement, whites have agreed with one another not to

\footnotetext{
${ }^{7}$ Nikki Giovanni, Sacred Cows and Other Edibles (New York: William Morrow, 1988),

57.

8 Aimé Césaire, Discourse on Colonialism, trans. by Joan Pinkham (New York, NY: Monthly Review Press, 2000), 32.

(c) 2018 Mark W. Westmoreland

https://www.kritike.org/journal/issue 23/westmoreland december2018.pdf ISSN 1908-7330
}

(c) $)$ BY-NC-ND 
recognize black persons as persons of equal standing. And, as the contract attempts to protect property, whiteness itself becomes property. "Where whiteness itself becomes property," Mills claims, "nonwhites do not fully, or at all, own themselves, and nonwhite labor does not appropriate nature." 9 Nonwhiteness - or I'll say "blackess" for clarity - has instrumental value for whiteness. Du Bois's "wages of whiteness" name those benefits accrued to whites due to a racial polity that attaches whiteness to property. This has two steps: whiteness is defined as oppositional. Where white equals virtue and citizen, black equals vice and anticitizen, that is, a Caliban needing to be controlled. If whiteness is a differential entitlement or property, then blackness cannot be. To be clear, whiteness in this context, while not disassociated from identity, speaks to the material benefits that whiteness confers. In other words, whiteness means that one owns differential treatment in the social sphere (political, legal, economic, etc.). Put differently, the goal of the racial polity, which assumes black inferiority as natural/apolitical, is to continually subordinate nonwhite racial groups in the interest of serving whiteness. According to Sartre, one of Césaire's interlocutors, the nature of "Colonialism [is to deny] human rights to [those] whom it has subdued by violence, and keeps them by force in a state of misery and ignorance that Marx would rightly call a subhuman condition. Racism is ingrained in actions, institutions, and in the nature of the colonialist methods of production and exchange." 10 A civilization that accepts this is only nominally civilized. The West is Hitler and has been since the dawn of colonization. The Führer did not appear from nowhere; rather his stage was already set long before he arrived. He was the consequence of an already decadent, sick civilization. Césaire tells us that "no one colonizes innocently."11. In short, all of the West is Hitler and has been so centuries before 1933.

To colonize is to "thingify." The colonizer defends himself in the name of progress. What he does not accept is his culpability in dehumanizing a large portion of the world. However, when the West takes pride in curing diseases and improving standards of living, Césaire laments the "societies drained of their essence ... lands confiscated ... magnificent artistic creations destroyed, [and] extraordinary possibilities wiped out." 12 While the oppressor points to roads, canals, railroads, and other infrastructure, Césaire looks upon "thousands of men sacrificed...millions of men torn from their gods, their

\footnotetext{
${ }^{9}$ Charles Mills, The Racial Contract (Ithaca, NY: Cornell University Press, 1997), 96.

${ }^{10}$ Jean-Paul Sartre, Introduction to Albert Memmi, The Colonizer and the Colonized (Boston, MA: Beacon Press, 1965), xxiv.

${ }^{11}$ Césaire, Discourse, 39.

${ }^{12}$ Ibid., 43.
}

(c) 2018 Mark W. Westmoreland https://www.kritike.org/journal/issue 23/westmoreland december2018.pdf ISSN 1908-7330 


\section{CÉSAIRE'S REVOLUTION OF PEDAGOGY}

land, their habits, their life." 13 The West sees trade and agricultural expansion. Césaire sees "food crops destroyed, malnutrition permanently introduced...about the looting of products [...] of raw materials." 14 The cynegetic logic of racism and colonialism results in only exploitation and domination. There are colonials and there are things.

The figure of Caliban in Shakespeare's The Tempest, given a voice of his own by Césaire, marks the present human condition, that is, the dialectical relation between reason and antimodernity that is part of a larger colonial project. The Caliban problem, explains Negri in The Savage Anomaly, is "the problem of the liberatory force of natural imagination." 15 The Caliban figure functions as the limit of reason. The problem for moderns is how best to deal with those who do not share the same epistemic and normative framework. For Negri, this problem is twofold: to what extent is imagination a means through which we navigate the vicissitudes of life and to what extent does the imagination play a role in the constitution of soul and world. In Commonwealth, Negri, along with Michael Hardt, explains how modern rationalism developed concurrently with the monstrous. The latter, for Hardt and Negri, names the antimodernity that grounds modernity's Caliban problem. These antimodern monsters-the forces allegedly threatening European enlightenment-were becoming all too familiar. Journal entries describing cannibalism, tales of human sacrifice, and reports of witches tormenting the hillside fed into the narrative of Europe's need to control such "creative powers" either by slavery, witch hunts, or colonialism. Cannibalism and sacrifice, albeit outside of Europe, pointed to a disposition of "cruelty, violence, and madness," while witches, both external and internal to Europe, were the manifestation of "irrationality and superstition, betraying reason and religion." 16 These monsters were met with one of two responses: either Europe tried to control them or it chose to disregard them, naming them "illusions, figments of an overheated imagination." 17 The figure of Caliban marks the present human condition, that is, the dialectical relation between reason and antimodernity that is part of a larger colonial project.

At the edge of the map, beyond the cartography of reason, here there be monsters-hic sunt dracones. In other words, "the dialectic brings the relationship to a standstill" in that modernity is equated with progress circumscribed by the stagnation of antimodernity. ${ }^{18}$ In their retort, Hardt and

\footnotetext{
13 Ibid.

${ }^{14}$ Ibid.

${ }^{15}$ Antonio Negri, The Savage Anomaly: The Power of Spinoza's Metaphysics and Politics, trans. by Michael Hardt (Minneapolis, MN: University of Minnesota Press, 1991), 86.

${ }_{16}$ Michael Hardt and Antonio Negri, Commonwealth (Cambridge, MA: Harvard University Press, 2009), 95.

17 Ibid.

${ }^{18}$ Ibid., 96.

(C) 2018 Mark W. Westmoreland

https://www.kritike.org/journal/issue 23/westmoreland december2018.pdf

ISSN 1908-7330
}

(c) BY-NC-ND 
Negri suggest that the problems of the Frankfurt description can be avoided. Rather than being in contradiction, rather than being oppositional, antimodernity has a diagonal relation to modernity. It cuts across the narrative of modern progress by opening up new possibilities for human progress. "The monsters of liberation," Hardt and Negri write, "because the most powerful of them, and the ones that will interest us most, do not stand in a specular, negative relation to modernity but rather adopt a diagonal stance, [are] not simply opposing all that is modern and rational but [are] inventing new rationalities and new forms of liberation." 19

It was the black slave who signified antimodernity. The black slave had to be put to work within a system of white supremacy. Turning to Shakespeare's The Tempest, Hardt and Negri note how Caliban, as the savage monstrosity, will not be killed by Prospero since he and his daughter Miranda need Caliban:
We cannot miss him.
He does make our fire,
Fetch in our wood, and serves in offices
That profit us. ${ }^{20}$

Contra this portrait of Caliban, anticolonial authors and theorists like Césaire have used Caliban to signify the struggle of resistance against the empires of modernity. For example, in Césaire's retelling of $A$ Tempest, Caliban gains his freedom by breaking the Manichean chains that imprisoned him, chains that were both physical and psychological. Caliban realizes that, rather than being incompetent and irrational, he has a form of reason that runs diagonal to that of European modernity. Hardt and Negri summarize the tension between Prospero and Caliban quite well:

From the perspective of the European colonizers the monster is contained in the dialectical struggle between reason and madness, progress and barbarism, modernity and antimodernity. From the perspective of the colonized, though, in their struggle for liberation, Caliban, who is endowed with as much or more reason and civilization than the colonizers, is monstrous only to the extent that his desire for freedom exceeds the bounds of the colonial relationship of biopower, blowing apart the chains of the dialectic. ${ }^{21}$

\footnotetext{
${ }^{19}$ Ibid., 97.

${ }^{20}$ William Shakespeare, The Tempest, I.2.310-312.

${ }^{21}$ Hardt and Negri, Commonwealth, 98.
} 


\section{CÉSAIRE'S REVOLUTION OF PEDAGOGY}

Such horrors of controlling the magical monster were buttressed by the political imaginary of modernity - one that understood the other, that is, the Amerindian, the African, and so on, as the functional limit of reason, as the body in opposition to thought. The body was understood as an external marker of a threat to rationality; as such, it was associated with the devil. Surveying journals and other documents made by European explorers and traders, Anthony Barker concludes: "Devil worship and diabolical interventions were the most widely reported aspects of the non-European societies the slave traders encountered." 22 Any conjuration or agreement made between slaves and the indigenous underclass was seen by the slaveholders and merchants as akin to the pact made between the devil and a witch. Such Calibans are not to be tolerated in the white, racial polity.

Whiteness disguises its imaginary force as a sociopolitical construction by accounting for race in terms of nature, namely, what will later be the domains of biology and genetics. Whiteness names a set of power relations through which "human" is defined in relation to the monstrous other (Caliban) - the African Negroes, the cannibals, those who practice human sacrifice, those who practice divination and a malicious alchemy. These others are to be controlled and either placed in bondage or exterminated. But, this illustrates how modernity cannibalizes itself, how it is its very own opposite. Césaire writes: "That the West alone knows how to think; that at the borders of the Western world there begins the shadowy realm of primitive thinking, which, dominated by the notion of participation, incapable of logic, is the very model of faulty thinking." ${ }^{23}$ In other words, by thinking its own rationality superior to others, modernity reveals itself as a monstrosity. For Mills, it is from the exclusion of others - the antimodernsthat the modern notion of the human-the liberal subject or the autonomous individual-is established in modernity. In the racial polity, for whites the game is to include whiteness and exclude the other.

"Every day that passes," Césaire writes, "every denial of justice, every beating by the police, every demand of the workers that is drowned in blood, every scandal that is hushed up brings home to us the value of our old societies." 24 And yet, he does not call for a return to the democratic and cooperative cultures of precolonial Africa. In Discourse, there is no call to revert to a premodern condition; there is no retreat to the past. Like Frantz Fanon after him, Césaire offers not naïve nostalgia but revolution. To return would be to repeat a history that cannot survive in the present; it is simply

\footnotetext{
${ }^{22}$ Anthony J. Barker, The African Link: British Attitudes to the Negro in the Era of the Atlantic Slave Trade, 1550-1807 (Totowa, NJ: Frank Class, 1978), 91.

${ }^{23}$ Césaire, Discourse, 64.

${ }^{24}$ Ibid., 44.

(c) 2018 Mark W. Westmoreland

https://www.kritike.org/journal/issue 23/westmoreland december2018.pdf

ISSN 1908-7330
}

(c) BY-NC-ND 
exoticism. For Césaire, the goal is not to choose from the preexistent options but to construct a way of life, a style, an aesthetics of the existence, to create something new by embracing both "the productive power of modern times" and "the fraternity of the olden days." 25

\section{Pedagogues and Public Intellectuals}

Robin D.G. Kelley's introduction to Césaire's Discourse ends with a powerful description of Césaire's text: It "never intended to be a road map or a blueprint for revolution. It is poetry and therefore revolt. It is an act of insurrection .... It is a rising, a blow to the master who appears as owner and ruler, teacher and comrade. It is revolutionary graffiti painted in bold strokes." ${ }^{26}$ Discourse is no blueprint, but it is revolutionary, or, as Kelley describes it, "a declaration of war ... almost a 'third world manifesto'." 27 Just as Césaire challenged his contemporaries and called for revolutionary practices that would put an end to colonization, its corrupt institutions, and its dehumanizing policies, his words still speak truth to a world marred by neocolonialism, rampant inequalities, and perverse capitalism, which, according to Marx, began with the cynegetic practice of hunting of black skins. Many of the social ills that confronted Césaire have yet to be remedied; not "every denial of justice" has been answered. ${ }^{28}$ Nevertheless, his call for resistance and revolution continues to encourage and challenge us to create "a humanism made to the measure of the world," a world with parity of participation among all. ${ }^{29}$

In Toward the African Revolution, Fanon asks, "Have I not, because of what I have done or failed to do, contributed to an impoverishment of human reality?" 30 Like Marx, Fanon realized the task before him was to change the world and not only to interpret it. The public intellectual's task is to improve human reality, to change the world, by placing herself in medias res alongside those suffering under, for example, the steel grip of racism or imperialism. This is not easily done for the intellectual is already in a double bind and is caught within a web of contradictions. The public intellectual, according to Sartre, receives her vocation from no one; her function is not mandated to her. The dominant, bourgeois class recognizes the public intellectual only as an intellectual in so far as she is a technician of knowledge whose task it is to

${ }^{25}$ Ibid., 52.

${ }^{26}$ Robin D.G. Kelley, "A Poetics of Anticolonialism," Introduction to Aimé Césaire, Discourse on Colonialism, trans. by Joan Pinkham (New York, NY: Monthly Review Press, 2000), 28.

${ }^{27}$ Ibid., 7.

${ }^{28}$ Césaire, Discourse, 44 .

${ }^{29}$ Ibid., 73.

${ }^{30}$ Frantz Fanon, Toward the African Revolution (New York, NY: Grove Press, 1967), 3.

(c) 2018 Mark W. Westmoreland https://www.kritike.org/journal/issue 23/westmoreland december2018.pdf ISSN 1908-7330 


\section{CÉSAIRE'S REVOLUTION OF PEDAGOGY}

perpetuate the advantages of the dominant class. As a "custodian of tradition," she is expected to be conservative. ${ }^{31}$ At the same time, the underprivileged class views her with much skepticism. She gets her own advantage, namely, education and sufficient employment, from the surplus value produced by the exploitation of the lower class by the dominant class. Any solidarity she may show toward this class meets distrust as she "is not one of us, she cannot understand our oppression." The middle class, of which she belongs, shares her contradictions but ignores them and welcomes the present ideology. The middle-class mass clamors "I too can be successful. I can be wealthy. I can have power." as if these things came about solely through a liberalism, colorblind and naïve, that buys into the idea that "if I only work hard enough, nothing can stand in my way." But, there is something in the way for the underclass and the racially oppressed, namely, the white supremacist patriarchy. Colonialism did not emerge from happenstance. It was not some accidental, historical enigma of Western civilization. Rather, it proceeded from the logic that undergirds the Eurocentric monologue of the West. It is against this monologue, which Césaire addresses in the final section of Discourse, that Négritude stands as a corrective, as one piece of what we might call a transformative remedy.

The public intellectual has a second problem, namely, his position. Trying to investigate himself and the conditions of which he is a product, the public intellectual lacks a view from the outside. If he wants to properly grasp the situation, then, according to Sartre, "he has only one course open to him and that is to adopt the point of view of its most under-privileged members," who, by their very existence, condemn the dominant ideology. ${ }^{32}$ While adopting this view, the public intellectual takes on several tasks, namely:

1. To struggle against ideology's rebirth

2. To elevate popular culture

3. To aid the underprivileged class in creating technicians of practical knowledge

4. To realize that the democratization of knowledge, freedom of thought, and truth are ends shared by all

5 . To demonstrate that immediate aims fall short of our ultimate objectives

6. To guard the "historical ends pursued by the masses, against all political power 33

\footnotetext{
${ }^{31}$ Jean-Paul Sartre, "Plea for Intellectuals," in Between Existentialism and Marxism (New York: William Morrow, 1976), 238.

32 Ibid., 235.

${ }^{33}$ Ibid., 262-263.

(c) 2018 Mark W. Westmoreland

https://www.kritike.org/journal/issue 23/westmoreland december2018.pdf

ISSN 1908-7330
}

(c) BY-NC-ND 
Noting these tasks reminds us that theory and practice do not belong to separate spheres. There is no pure theory; theory is a practice. Césaire and others were already doing this. Fanon, Léopold Senghor, and other Négritude artists were already turning an antiracist, anticolonial theory into a revolution of minds and a revolutionary aesthetics of existence.

There is nothing original in my claim that colonialism was destructive and abhorrent. In The Notebook of a Return to the Native Land, Césaire writes,

At the end of daybreak, life prostrate, you don't know how to dispose of your aborted dreams, the river of life desperately torpid in its bed, neither turgid nor low, hesitant to flow, pitifully empty, the impartial heaviness of boredom distributing shade equally on all things, the air stagnant, unbroken by the brightness of a single bird. ${ }^{34}$

While the colonial system brought a cloud of darkness over the earth, the selfdetermination of the colonized gave and still gives us hope that brighter days are possible. But before such bright days come, the unheard must become heard. The pedagogue must, as Spivak suggests, learn to learn from below. Those below know that the new world, which lingers at the end of history, comes about at the end of this world. Such a new pedagogy would, in Césaire's view, bring down the reign of Prospero.

Césaire writes in response to the monologue of white normative and white supremacist thinking: "And the voice [that is, the voice of Africa] complains that for centuries Europe has force-fed us with lies and bloated us with pestilence, for it is not true that the work of man is done, that we have no business being on earth, that we parasite the world." 35 The European Prospero sees the Calibans of the world as a threat to the cosmic order of whiteness. In reply, Caliban speaks:

Prospero, you are the master of illusion.

Lying is your trademark.

And you have lied so much to me

(lied about the world, lied about me)

that you have ended by imposing on me

an image of myself.

Underdeveloped, you brand me, inferior,

${ }^{34}$ Aimé Césaire, Notebook of a Return to the Native Land (Middletown, CT: Wesleyan University Press, 2001), 9.

${ }^{35}$ Ibid., 44.

(c) 2018 Mark W. Westmoreland

https://www.kritike.org/journal/issue 23/westmoreland december2018.pdf

ISSN 1908-7330

(cc) BY-NC-ND 


\title{
32 CÉSAIRE'S REVOLUTION OF PEDAGOGY
}

that's the way you have forced me to see myself.

I detest that image! What's more, it's a lie!

But now I know you, you old cancer, and I know myself as well. ${ }^{36}$

Césaire, like Du Bois before him, rejects Prospero's colonizing claim: modern European civilization destroyed the beautiful cultures of Africa and, once politically and socially free, the Negro peoples will again create a new way of life, a new "humanism made to the measure of the world." 37

\section{Revolution}

Revolution transforms the potential into the actual. In the era of decolonization, "revolution was [a] way of life," a way of renewing the realm of the possible. ${ }^{38}$ What was becoming actualized was not simply access to subsistence, not simply the struggle for bare life; but, also, it was a struggle for dignity, for recognition of "[the negroes'] full human value." 39 The primary condition for the creation of dignity, value, and culture, according to Césaire, is destruction - the end of the world - a revolution. Césaire writes in Notebook:

\author{
What can I do? \\ One must begin somewhere. \\ Begin what? \\ The only thing in the world \\ Worth beginning: \\ The End of the world of course. ${ }^{40}$
}

Let me briefly lay out a historical account of revolution and what this might mean for the twenty-first century. First, revolution is not synonymous with war nor should it be confused with revolt. Human histories are full of wars, but revolutions came about only in the recent past. While they might be violent, they are not carried out in order to acquire the resources of another

36 Aimé Césaire, A Tempest, trans. by Richard Miller. (New York, NY: Theatre Communications Group, Inc., 2002), 61-62.

${ }^{37}$ Césaire, Discourse, 73.

${ }^{38}$ Adolfo Gilly, Introduction to Frantz Fanon, A Dying Colonialism (New York: Grove Press, 1965), 1.

${ }^{39}$ Ibid., 58.

${ }^{40}$ Césaire, Notebook, 22.

(c) 2018 Mark W. Westmoreland

https://www.kritike.org/journal/issue 23/westmoreland december2018.pdf

ISSN 1908-7330

(c) BY-NC-ND 
people, as is often common in wars, nor are they pursued solely for the sake of regime change; in other words, revolutions are not coup d'etat. When Louis XVI saw the beginnings of what would become the French Revolution, he called it a revolt. This was just two days before the storming of the Bastille. A French Duke, standing next to the king responded, "Sire ... it is not a revolt, it is a revolution." 41 (Williams 272). What this little anecdote shows is how revolution was beginning to take on a new meaning and one that we should ask whether or not is still fitting for our contemporary time.

The term revolution has a wide lexical range. It may refer to planetary cycles, such as the orbit of the earth around the sun, for example. It may refer to groundbreaking shifts in paradigms, as when, for instance, we speak of the Copernican revolution in science or the Kantian revolution in philosophy. In addition, an older notion of political revolution may be found in the ancient Greeks and Romans but such a revolution was linked with the natural order of the world. This older notion of revolution held that one regime or constitution at a time could structure the polis. The regimes might emerge in cycles, one replacing another in a continuous political orbit, but nothing radically new was created. What was lacking in this sort of revolution was a transformation of the social order.

Modern revolution, however, involves both political and social newness. Furthermore, it does not participate in a recurring cycle. According to Hannah Arendt, "the modern concept of revolution, inextricably bound up with the notion that the course of history suddenly begins anew, that an entirely new story, a story never known or told before, is about to unfold, [that!] was unknown prior to the two great revolutions at the end of the eighteenth century." 42 Revolution is seen here, not as a return to an earlier state of affairs, but as a radical break from previous modes of social and political life. This unprecedented event opens up an unknown future in which society is reconfigured or transformed. In the modern context of the decolonization, the question remains whether political emancipation or liberation also involves social progress and freedom-the freedom to determine one's own destiny. Such freedom or self-determination cannot arise from mere reforms since reforms do not dismantle the architecture of systemic oppression. As remedies, they might tweak this or that, but, if the foundation of society is already unjust, the rest of the house will remain tainted. Revolution, however, is the beginning of a transformative remedy that "aim[s] at correcting inequitable outcomes precisely by restructuring the

${ }^{41}$ Raymond Williams, Keywords: A Vocabulary of Culture and Society (New York: Oxford University Press, 1985), 272.

${ }^{42}$ Hannah Arendt, On Revolution (New York, NY: Penguin Books, 2006), 18-19.

(c) 2018 Mark W. Westmoreland

https://www.kritike.org/journal/issue 23/westmoreland december2018.pdf

ISSN 1908-7330

(cc) BY-NC-ND 


\section{CÉSAIRE'S REVOLUTION OF PEDAGOGY}

underlying generative framework" of society. ${ }^{43}$ This restructuring involves more than minor, surface reforms. Reforms might lessen the negative effects of colonization and systemic racism but they will not abolish them. A remedy is transformative on two counts in the way that it produces parity of participation. It attempts to significantly restructure both the relations of production so that material conditions are equalized, so that resources such as wealth and opportunity are evenly distributed, and also the relations of recognition so that all members of society are seen as equal peers.

\section{Intellectuals and Revolution}

"What Césaire destroys," Sartre suggests, "is not all culture but rather white culture; what he brings to light is not desire for everything but rather the revolutionary aspirations of the oppressed negro; what he touches in his very depths is not the spirit but a certain specific, concrete form of humanity." 44 The soul of revolution is imagination and Césaire, as a public intellectual, helped develop a critical consciousness for the wretched of the earth. The imagination opens up new possibilities in both thought and practice, new changes in human social interaction. Revolutionary aspirations find their actualization in the work of the oppressed masses, who alone are the miraculous weapons of liberation. Often, the biggest hindrance is the "decent fellow," or the white moderate, or the false intellectual. ${ }^{45}$ The public intellectual, however, serves as a corrective. She is from the middle class, same as the "decent fellow," and can challenge the moderate's acceptance of the dominant ideology. Whereas the moderate says no to radical change, no to violent revolution, no to the abolition of capitalism, the Sartrean public intellectual, of which Césaire is paradigmatic, says "if all I can do is speak, it is for you [the colonized, that] I shall speak." 46 Where white supremacist patriarchy attempts to fragment the oppressed, thereby rendering them mute, the revolutionary poet, the public intellectual, gives unreserved "support [to] the national aspirations of colonized peoples." 47 While the liberal focuses on reforming society in order to reduce individual racism, Césaire, according to André Breton, is "a black who is not only a black but of all of [humankind], who conveys all of [our] questionings, all of [our] anguish, all of [our] hopes and all of [our] ecstasies, and who will remain more and more [...] the prototype of dignity" that stands defiantly before the monster that is systemic

${ }^{43}$ Nancy Fraser, Justice Interruptus: Critical Reflections on the "Postsocialist" Condition (New York, NY: Routledge, 1996), 23.

${ }^{44}$ Sartre, "Black Orpheus," 127.

${ }^{45}$ Césaire, Discourse, 47.

${ }^{46}$ Césaire, Notebook, 13.

${ }^{47}$ Fanon, Toward the African Revolution, 76.

(C) 2018 Mark W. Westmoreland

https://www.kritike.org/journal/issue 23/westmoreland december2018.pdf

ISSN 1908-7330

(c) BY-NC-ND 
racism. ${ }^{48}$ It is from being one from below, one of the wretched, that one can speak for all in so far as he gives voice to what whiteness tried to make invisible. And finally, what is this new kind of dignified life? What is the alternative to liberal reform? What is the concrete alternative? These questions are meaningless in so far as there is no a priori blueprint. Before the revolution begins and in the midst of revolution itself, the revolutionary actors do not have a view of the future of this world. They call for its end. Césaire's Discourse is not a blueprint, but it does provide a ground upon which we can imagine a new body politic, one that is generated from within the ranks of the colonized. The colonized know the end of the world, and yet, at the same time, know of a "humanism made to the measure of the world."

Department of Philosophy, Villanova University, USA

\section{References}

Arendt, Hannah, On Revolution (New York, NY: Penguin Books, 2006).

Barker, Anthony, The African Link: British Attitudes to the Negro in the Era of the Atlantic Slave Trade, 1550-1807 (Totowa, NJ: Frank Cass, 1978).

Breton, André, "A Great Black Poet," in Aimé Césaire, Notebook of a Return to the Native Land (Middletown, CT: Wesleyan University Press, 2001).

Césaire, Aimé, A Tempest, trans. by Richard Miller (New York, NY: Theatre Communications Group, Inc., 2002).

"Culture and Colonization," Social Text, 28:2 (2010).

Discourse on Colonialism, trans. by Joan Pinkham (New York, NY:

Monthly Review Press, 2000). Notebook of a Return to the Native Land (Middletown, CT:

Wesleyan University Press, 2001).

"The Thoroughbreds," in The Collected Poetry, trans. by Clayton

Eshleman and Annette Smith (Berkeley, CA: University of California

Press, 1983).

Drabinski, John E., "Césaire's Apocalyptic Word," South Atlantic Quarterly, 115:3 (2016).

Fanon, Frantz, Toward the African Revolution (New York, NY: Grove Press, 1967).

Fraser, Nancy, Justice Interruptus: Critical Reflections on the "Postsocialist" Condition (New York, NY: Routledge, 1996).

Freire, Paulo, Pedagogy of the Oppressed (New York: Continuum, 2007).

48 André Breton, "A Great Black Poet," in Notebook of a Return to the Native Land (Middletown, CT: Wesleyan University Press, 2001), xii.

(c) 2018 Mark W. Westmoreland https://www.kritike.org/journal/issue 23/westmoreland december2018.pdf ISSN 1908-7330 


\section{CÉSAIRE'S REVOLUTION OF PEDAGOGY}

Gilly, Adolfo, Introduction to Frantz Fanon, A Dying Colonialism (New York: Grove Press, 1965).

Giovanni, Nikki, Sacred Cows and Other Edibles (New York: William Morrow, 1988).

Hardt, Michael, and Antonio Negri, Commonwealth (Cambridge, MA: Harvard University Press, 2009).

Kelley, Robin D.G, "A Poetics of Anticolonialism," Introduction to Aimé Césaire, Discourse on Colonialism, trans. by Joan Pinkham (New York, NY: Monthly Review Press, 2000).

Mills, Charles, "Racial Polity," in Blackness Visible (Ithaca, NY: Cornell University Press, 1998). The Racial Contract (Ithaca, NY: Cornell University Press, 1997).

Negri, Antonio, The Savage Anomaly: The Power of Spinoza's Metaphysics and Politics, trans. by Michael Hardt (Minneapolis, MN: University of Minnesota Press, 1991).

Sartre, Jean-Paul, "Black Orpheus," in Race, ed. by Robert Bernasconi (Malden, MA: Blackwell, 2001).

Introduction to Albert Memmi, The Colonizer and the Colonized (Boston, MA: Beacon Press, 1965). "Plea for Intellectuals," in Between Existentialism and Marxism (New York: William Morrow, 1976).

Shakespeare, William, The Tempest, in The Riverside Shakespeare: The Complete Works, $2^{\text {nd }}$ ed. (Boston, MA: Houghton Mifflin, 1997).

Walker, Alice, In Search of Our Mother's Gardens, (San Diego, CA: Harcourt Brace Jovanovich, 1983).

Williams, Raymond, Keywords: A Vocabulary of Culture and Society (New York: Oxford University Press, 1985).

(c) 2018 Mark W. Westmoreland https://www.kritike.org/journal/issue 23/westmoreland december2018.pdf ISSN 1908-7330

\section{(c) ) BY-NC-ND}

